\title{
THE RELATIONSHIP BETWEEN WASTE DISPOSAL PROBLEMS AND THE KNOWLEDGE, ATTITUDES AND PRACTICES OF THE KUALA TERENGGANU COMMUNITY
}

\author{
Nursabrina Abdullah"1, Mohd Khairul Amri Kamarudin", ${ }^{1,}$, Noorjima Abd Wahaba ${ }^{2}$, Muhammad Hafiz Md Saad ${ }^{2,3}$, Siti Nor Aisyah Md Bati², \\ Tepvisit Potikengrith ${ }^{4}$ \\ 1 Faculty of Applied Social Science, Universiti Sultan Zainal Abidin, Kampus Gong Badak, 21300 Kuala Nerus, Terengganu, Malaysia \\ ${ }^{2}$ East Coast Environmental Institute (ESERI), Universiti Sultan Zainal Abidin, Kampus Gong Badak, 21300 Kuala Nerus, Terengganu, Malaysia \\ ${ }^{3}$ AB Bakti Enterprise, Lot 27215 Kg. Gong Kuin 2, Jalan Tok Jembal, 21300 Kuala Nerus, Terengganu, Malaysia \\ ${ }^{4}$ Special Branch Police Bureau, Bangkok, Thailand \\ *Corresponding Author Email: mkhairulamri@unisza.edu.my
}

This is an open access article distributed under the Creative Commons Attribution License, which permits unrestricted use, distribution, and reproduction in any medium, provided the original work is properly cited.

\section{ARTICLE DETAILS}

Article History:

Received 19 August 2019 Accepted 23 September 2019

Available online 09 October 2019

\section{ABSTRACT}

This article applies the bits of the relationship between waste disposal problems and the knowledge, attitudes and practices of the community living in Kuala Terengganu, Terengganu Malaysia. As the rapidness of development in this state, the issue of waste disposal is getting serious day by day. This article discusses a lot on how the knowledge, attitudes and practices of the society affected the waste disposal problems and how does the system of waste disposal running in this area. The aims of this study are to overcome the waste disposal problem and raise awareness in maintaining environmental hygiene. The results of this study show that the knowledge, attitude and practice are closely related to each factor and also affect the waste disposal issues. It is important for the community to increase awareness and knowledge, improve behavior and practice in maintaining the well-being of life while maintaining ecosystems and environment of the nature.

\section{KEYWORDS}

Waste Disposal Issue, Waste Management, Environmental, Attitude and Practice, Kuala Terengganu Community.

\begin{abstract}
1. INTRODUCTION
The achievement of Malaysia's financial advancement has been an incredible dimension and this achievement has been perceived by other universal nation. This accomplishment because of the administration's responsibility and endeavors to execute advancement tasks including the development of new towns, foundation and open offices. This development also includes the facilities of the cities including public transports. This change prompts the flighty society towards condition that will influence the personal satisfaction. However, the growing of this financial advancement also has resulted in the changing of environment status as in cleanliness of the surrounding, the knowledge of the society and also their practicing and attitudes in keeping the environment clean and safe [1].
\end{abstract}

Waste as indicated by EU Waste Directive (2008) is any substance which proprietor disposes of or expects to dispose of for any purposes. A group of researchers as referred to another researcher, considers loss to be any material ordered to be squander by national enactment or any materials that is never again helpful that should be discarded $[2,3]$. According to a study, waste can be characterized in numerous structures relying upon the class or setting its being utilized [4]. It can essentially be characterized as any material viewed as pointless which means it is never again requirement for it plans reason. This matter also showed that, when something no longer valuable to somebody, it is helpful to someone else in this manner somebody's waste is somebody's crude material.

Based on a research, it has been perceived by analysts that it is imperative to make practical waste frameworks just as advancing natural citizenship among network individuals through improved open mindfulness and network cooperation in waste administration as well as enhancing the awareness and knowledge in community [5,6]. Attitudes and practices of the citizen also give a great impact towards the sustainability of the environment especially in waste disposal problems. A study led in Malaysia came about that, to defeat the strong waste emergency, Inner voice of the individual should be raised through ecological knowledge and concern, teaching of reasonable utilization practices and instruction on waste administration [7].

According to a study, the negative conducts with strong waste administration in most creating nations are on littering which has a ton of causes [8]. These causes incorporate absence of social strain to anticipate littering, nonappearance of sensible punishments or steady requirement, and absence of learning of the natural impacts of littering. This problem also happened when if there are a lack of enhancement and enforcement of the penalties by the government. The attitudes of littering can affect in developing of bad practices in daily life routines [9].

\section{LITERATURE REVIEW}

This study needs a high understanding of the concept of waste, how waste disposal happens and how does waste disposal problems related with the knowledge, attitudes and practices of the community based on previous studies by other researchers. Waste is comprised of natural and inorganic waste materials that happens because of human and creature exercises and never again required in life which should be disposed because of its worth misfortune to the client [10]. Be it utilized plastic bags, broken glass, out of date wireless, or utilized battery cells, they are altogether utilized items that required proper transfer to restrain their damage to nature. Waste transfer is consequently a methodical activity for overseeing waste 
from its cause to its last transfer. It incorporates cremation and copying, internment at landfills destinations or release in lake or stream and reusing.

In Kuala Terengganu, around March of 2019, the authorities in Kuala Terengganu happened to clean up about a ton of trash caught in the ditch within one to three months. This happens because of the practices of throwing rubbish by the society. A researcher said communities especially those who living near rivers and ditches should cooperate with local authorities to keep the environment clean [11]. The immoral act of letting junk and food waste piled on the edge of the field after breaking fast around May 2019 also in Kuala Terengganu. A researcher stated that within a week, the amount of waste rise about 24 tones [12]. This showed that, especially during festival and celebration, citizens tend to let their waste piled on any places nearer them even when there is a lot of bin provided by the authorities.

Nature frame of youngsters show up to be vital as they at last play a direct job in giving information-based answers for in-coming natural issues [13]. A researcher stated that school natural programs, despite the fact that routed to understudies can likewise impact upon the ecological information, demeanor and conduct of grown-ups (guardians, educators, nearby network individuals) through the procedure of intergenerational impact. Here in Kuala Terengganu, because of absence of instruction and mindfulness in waste administration, people in different networks go to reprimand the legislature for ill-advised waste administration. According to a previous researcher, absence of enthusiasm for the earth realizes a culture of non-interest of networks in basic leadership forms which upgrades absence of obligation regarding contamination, littering and waste issues.

Most citizens have the attitudes and mindset of not worry of waste administration which decreases their awareness in this matter. This is the reason that most network individuals are not engaged with basic leadership so along these lines build up the demeanor of not concern which makes them not in charge of waste administration. This frame of mind varies among financial gatherings. Be that as it may, the demeanor and conduct of people can be emphatically impacted by executing quality waste administration frameworks to appropriately oversee waste produced. At the point when necessities for fundamental nourishment and safe house assimilate the consideration of the biggest part of the network, at that point numerous natural qualities are dismissed. This implies individuals who fulfill or are happy with their fundamental needs are delicate to the executives of waste.

Beside the context of knowledge and attitudes, the practices of the society also influenced in waste disposal issues. According to UN-Habitat (2010), for all intents and purposes, green management and waste system practices greatly affects our wellbeing in a domain [14]. A decent strong waste framework resembles great wellbeing subsequently if things are done well individuals will have agreeable life yet on the other hand, if things turn out badly, it is a major and dire issue which makes everything else appears to be less significant. Implementing a good practice based on the hierarchy of waste management also can help and engaging the citizen to apply a positive practice in their daily life routine. Mentality of not worry and concern about waste administration varies among financial gathering consequently; wealthier financial gatherings are bound to make contrast with regards to natural issues since they want to affect more in tending to and fixing the issue. These different levels of socioeconomics group tend to act differently based on their needs. Therefore, their attitude and practices differ from another socioeconomics group.

\section{DISCUSSIONS}

Waste disposal has been a major issue for the authorities and the nearby individuals in Kuala Terengganu. As we as a whole know, ill-advised strong waste administration can be unsafe to nature and surrounding, wellbeing just as the prosperity of society with other living and nonliving beings inside and past the dirtied territory $[15,16]$. This study took a gander at why ill-advised strong waste administration is an issue by contemplating the network's information, mentality and practices towards waste administration. The three networks' activity towards waste administration was because of hazy comprehension of duties, which is responsible for waste administration. It was acknowledged from the study, that the networks had a thought where government is in charge of anything with respect to squander.
Figure 1 shows the progression of waste management in developing countries. The waste progression is in pyramid structure which shows how activity should be taken. From the new hierarchy of managing process, the principal move must be made on avoiding the age of waste, trailed by lessening waste age (for example through re-use), reusing, fertilizing the soil or anaerobic assimilation, recuperation and waste tovitality and in the event that vitality isn't recouped from procedures, at that point it winds up in landfill. Based on UNEP (2013), as cited by Essuman Nasir (2017), squander transfer on landfills is the final retreat just when waste has not been forestalled, occupied or recouped in the procedure steps [17]. This new squander the board worldview is the turnaround of the conventional waste progressive system with the point of not guaranteeing consistence of waste administration guideline. Its attention is on improving constrained assets through forestalling waste age just as guaranteeing that waste is treated as an asset.

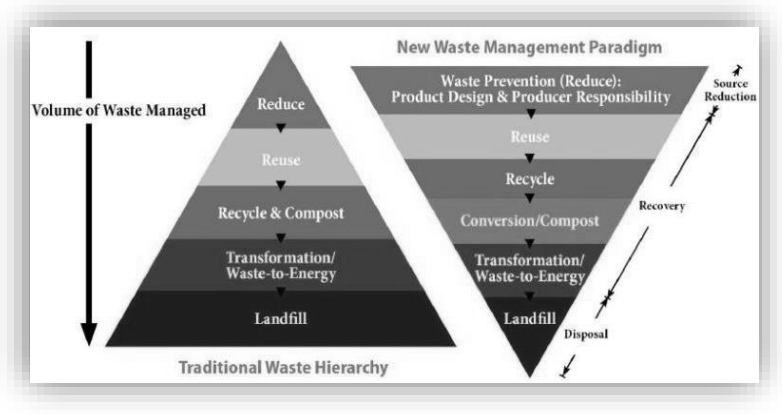

Figure 1: Hierarchy of Waste Management. (Source: [4])

Based on figure 1, the traditional hierarchy of waste management above, the first part of the hierarchy which is reduction or reduce played the main role in waste management system in order to prevent the waste disposal issues from getting worst. Knowledge, attitudes and practices are the three factors that can help the authorities to complete the first part of the waste management systems. These three factors play an important role in engaging the individuals who live in and nearer Kuala Terengganu. Knowledge as in awareness and education is the first way in keeping the society aware with the important of having a clean and healthy environment. The authorities in this area need to spread more knowledge to our youngster as they capable to mobilizing changes to our state and country.

Other than that, attitudes also played a same role as knowledge. People in any socioeconomics group should know that even they differ from each other, the responsibility of keeping our environment save and sound are our owns responsibility. Even when the government of the state has appointed the authority to conduct their duty, we as a human being should know that helping other people will not giving us any disadvantages.

Table 1 shows the schedule of waste collection service in Kuala Terengganu which has been conducted by MBKT (Kuala Terengganu City Council). This schedule of waste collecting explains that every 3 times in a week, the authorities will start to collect the waste from house to house within Kuala Terengganu area. For business premise, the operation was scheduled for every single day as the business premises operate for the whole week. As for common collection which is around main roads in Kuala Terengganu, the operation period was schedule for everyday and lapse of a day for hallways. This operation of waste collecting can affect in sustenance of cleanliness in Kuala Terengganu City.

Table 1: Waste Collection Service Schedule

\begin{tabular}{|c|l|l|}
\hline No. & \multicolumn{1}{|c|}{$\begin{array}{c}\text { Types of Waste } \\
\text { Collection }\end{array}$} & \multicolumn{1}{c|}{ Operation Period } \\
\hline 1 & $\begin{array}{l}\text { Waste collection from } \\
\text { house to house }\end{array}$ & $\begin{array}{l}3 \text { times in a week (Sunday, } \\
\text { Tuesday \& Thursday) }\end{array}$ \\
\hline 2 & $\begin{array}{l}\text { Waste collection at } \\
\text { business premise in city }\end{array}$ & Everyday \\
\hline 3 & \multicolumn{2}{|c|}{ Common collection } \\
\cline { 2 - 3 } & Main roads & Everyday \\
\cline { 2 - 3 } & Hallways & Lapse of a day \\
\hline
\end{tabular}

(Source: MBKT Official Portal, 2017)

Table 1 also shows that MBKT as the authorities that responsible in keeping Kuala Terengganu in a better surrounding really take a serious 
thought of having a clean and beautiful state. It does not make any sense if the worker itself did not doing their job that has been appointed. According to issue at Pesisir Payang, Kuala Terengganu this early Jun explained that the worker still doing their job in collecting the rubbish that has piled up at the field, but the attitudes of the society itself really has cross the line. The society needs to maintain the cleanliness of public areas as they maintain the cleanliness of their own homes. Any individuals need to have this kind of mindset so that they would not easily litter at public places. Speaking about attitudes, parents and teachers including any educators should show a better side of them in taking care of the environment especially with the act of not littering at any places towards their children and students.

As in practices in waste management in order to prevent the waste disposal issues, individuals who living in this area should be informed that the practices that they have been applying should be done and should be improve to a better practices such as recycling or reuse it if still can be innovate. Recycling culture need to be enhanced and improved to make it permanent as our culture. There is a lot of dispose product that can still be use in our society that should not be shoving. As stated in previous topic, the act of littering in this state need to be prevent totally. This is because, people who are littering at any places they went are selfish and did not concern about the environment and their generations future. These practices of littering are not giving us any benefit but unstable systems of waste disposal, unhealthy environment and dirty atmosphere [18,19].

\section{CONCLUSION}

It was acknowledged from the research that, waste disposal system in this state had difficulties which needs prompt activities. Waste was dumped everywhere which cause a lot of other issues such as water pollution, waste piled up at one place and many more. It was understood, that they knew about their activities relating to disposal management since they are seeing the impact however the fault is pushed on the administration as if they are not carrying out its responsibility. Citizen should realize that the authorities could not carry the responsibility at their fullest if the citizen did not aware of the importance in keeping the surrounding clean and if the act of littering still linger as the attitudes of the individuals.

Based on the research, this study shows that the factor of knowledge, attitudes and practices really influenced the waste disposal issues in this area. Generally, individuals who have knowledge and awareness in environmental issues will not do any immoral acts especially littering in public area. The attitudes and practices of someone in environmental acts really depend on their knowledge. If they are not aware about this waste disposal issues, the bigger chances for them to litter and doing negative attitudes towards nature. Practices of socioeconomic groups and communities also influenced towards this issue. People tend to follow their nearest individuals; families and neighbors. Youngsters especially kids are the easiest group in community that can easily follow and copy people attitudes and practices as their daily life routine.

In order to improve the quality of life in this area, both the authorities and community should collaborate and cooperate together to prevent this issue from getting worse. There's an improvement that the responsible authorities can use in order to enhance the quality of life and cleanliness of the city is, they can strengthen their policy and legalization towards people who are wrong, and they should not compromise towards those people. Other than that, the authorities also can hold a training program and campaigns on waste management which can start from their own house. These strategies at least can prevent the individuals who living in this area from having malaria, dengue, and any other diseases.

\section{ACKNOWLEDGEMENT}

The authors acknowledge the financial assistance from FRGS, SRGS and RAGS Grant: (FRGS/1/2017/WAB05/UNISZA/01/ 1) - RR222, (UniSZA/2017/SRGS/17) - R0019-R017 and RAGS/1/2015/WAB05/UNISZA/02/1, Faculty of Applied Social Sciences (FSSG), East Coast Environmental Research Institute (ESERI), Universiti Sultan Zainal Abidin (UNISZA) for giving us permission to utilize the research facilities, advice, guidance, and support for this study.

\section{REFERENCES}

[1] Badran, I.G. 1995. Knowledge, attitude and practice the three pillars of excellence and wisdom: a place in the medical profession.

[2] Morrison, J., Wray, R., Dever, S., Dunstan, L. 2000. Workshop on Waste Management for Developing Countries. University of Wollongong, Australia.

[3] Lutui, V. 2001. Waste management practices, perceptions and attitudes in Tonga. University of Wollongong.

[4] Essuman, N. 2017. Knowledge, Attitudes and Practices of Coastal Communities on Waste Management in Ghana, 5-18.

[5] Lumbreras Martín, J., Fernández García, L. 2014. Comprehensive solid waste management: The Ciudad Saludable model in Peru.

[6] McAllister, J. 2015. Factors Influencing Solid-Waste Management in the Developing World. All Graduate Plan B and other Reports, 528.

[7] Aini, M.S., Razi, A.F., Lau, S.M., Hashim, A.H. 2002. Practices, attitudes and motives for domestic waste recycling. International Journal of Sustainable Development and World Ecology, 9(3), 232.

[8] Al-Khatib, I.A., Arafat, H.A., Daoud, R., Shwahneh, H. 2009. Enhanced solid waste management by understanding the effects of gender, income, marital status, and religious convictions on attitudes and practices related to street littering in Nablus - Palestinian territory. Waste Management, 29(1), 449-455.

[9] Bonnett, M., William, J. 1998. Environmental Education and Primary Children's Attitudes Towards Nature and the Environment. Cambridge Journal of Education, 28(2), 159-174.

[10] Augustino, C., Bahati, L., Alexanda, M. 2015. Assessing the Awareness, Knowledge, Attitude and Practice of the Community towards Solid Waste Disposal and Identifying the Threats and Extent of Bacteria in the Solid Waste Disposal Sites in Morogoro Municipality in Tanzania.

[11] Baharom, B. 2019. Longgokan Sampah cemari dataran shahbandar dan pesisir payang. Berita Harian Online, Retrieved from https://www.bharian.com.my/berita/wilayah/2019/05/567521/longgo kan-sampah-cemari-dataran-shahbandar-dan-pesisir-payang [Access on 23/06/2019]

[12] Baharom, B. 2019. MBKT angkut satu tan sampah dari parit. Berita Harian Online, Retrieved from https://www.bharian.com.my/berita/wilayah/2019/03/540513/mbktangkut-satu-tan-sampah-dari-parit [Access on 22/06/2019]

[13] Paul F.J., Eagles \& Robert Demare. 1999. Factors Influencing Children's Environmental Attitudes, The Journal of Environmental Education, 30(4), 33-37.

[14] UN-HABITAT. 2010. Solid waste management in the world's cities. Nairobi: Unhabitat.

[15] Jamilah, H.A., Hasrina, M., Hamidah, A.H., Juliana, A.W. 2011. Pengetahuan, Sikap Dan Amalan Masyarakat Terhadap Isu Alam Sekitar. Akademika, 81(3), 103-115.

[16] Catherine, A. 2016. When Waste Disappears, Or More Waste Please! In No.1, Out of Sight, Out of Mind: The Politics and Culture of Waste. Rachel Carson Center, 31-40.

[17] United Nations Environment Programme (UNEP). 2013. Guidelines for National Waste Management Strategies, Moving from Challenges to Opportunities.

[18] Moore, S. 2012. Garbage Matters: Concepts in New Geographies of Waste. Progress in Human Geography, 36(6), 780-990.

[19] Agwu, M.O. 2012. Issues and Challenges of Solid Waste Management Practices in Port-Harcourt City, Nigeria - a behavioural perspective. American Journal of Social and Management Sciences, 3(2), 83-92. 